\title{
Sejarah Makassar dan Tradisi Literasi
}

\author{
ILHAM DAENG MAKKELO
}

Staf Pengajar Departemen IImu Sejarah Universitas Hasanuddin

dan penggiat Selarung Institute

Email: ilhamdaengmakkelo@gmail.com

\begin{abstract}
This article analyses two main topics; the history of the origin and development of the kingdom of Makassar in south Sulawesi and the historiography of the South Sulawesi area and its literary tradition. This area is one of the regions in Indonesia that has a literary tradition which developed since the appearance of the lontaraq script as a medium for the record keeping of political and social life of the community. Various literary classics have been produced from this tradition, such as the La Galigo epic, various state and social regulations, genealogy tracts and personal journals. The history and culture of south Sulawesi has become of particular interests for researchers in Indonesia and abroad. The central focus of its historiography has been the glory days of the kingdom of Makassar in the 16-17 th century. The centuries after the fall was a period of minimal production of literary and historical works. Its literary tradition made a resurgence in the post-colonial period but had sputtered out by the end of the 1960s. During the New Order period, the regime's strong control has reduced the space for literary expression and resulted in stagnating literary production. Since the Reformasi period, efforts to rejuvenate the literary tradition of south Sulawesi has appeared.
\end{abstract}

\section{Abstrak}

Tulisan ini mengkaji dua hal utama yakni sejarah muncul dan berkembangnya Kerajaan Makassar di Sulawesi Selatan, serta historiografi Sulawesi Selatan dan tradisi literasinya dari waktu ke waktu. Wilayah ini merupakan salah satu daerah di Indonesia dengan tradisi literasi yang ditandai munculnya huruf lontaraq sebagai media utama dalam mencatat segala aktivitas masyarakat maupun kehidupan politik. Berbagai karya tulis klasik lahir dari tradisi itu, seperti naskah La Galigo, aturan bernegara dan bermasyarakat, penulisan silsilah, dan catatan harian. Sulawesi Selatan juga merupakan wilayah penelitian sejarah dan budaya yang mendapat banyak perhatian para peneliti, baik dari dalam maupun luar negeri. Fokus utama historiografi selama ini terutama pada masa kejayaan Kerajaan Makassar pada abad ke-16-17. Beberapa abad setelah itu, menjadi periode yang minim dari karya literasi dan karya sejarah. Gairah literasi kembali muncul pasca-kolonial, namun hanya bisa bertahan hingga awal 1960-an. Pada masa Orde Baru, kontrol yang kuat dari rezim ini tidak memungkinkan tumbuhnya ruang ekspresi literasi secara leluasa, sehingga tidak lahir karya-karya literasi yang signifikan. Sejak reformasi, usaha menghidupkan budaya literasi di Sulawesi Selatan kembali muncul dengan berbagai cara.

\section{Keywords:}

Bugis; historiography; literacy; Makassar; South Sulawesi

\section{Kata Kunci:}

Bugis; historiografi;

literasi; Makassar; Sulawesi Selatan 


\section{Pengantar}

Sejak muncul dan berkembangnya Kerajaan Makassar, tradisi literasi sudah pula mengambil peran penting dalam kehidupan masyarakat di hampir seluruh wilayah Sulawesi Selatan. Di wilayah ini, lahir karya sastra epic La Galigo yang konon merupakan karya sastra klasik terpanjang di dunia. Selain itu, tercipta pula huruf Lontara, yang menjadi medium utama dalam mencatat aktivitas politik dan kemasyarakatan masa lalu, serta mendokumentasikan pengetahuan tentang ilmu pertanian, aktivitas kemaritiman, hingga pengobatan.

Dalam historiografi Sulawesi Selatan, periode abad ke-16 hingga abad ke-17 sebagai masa kejayaan Kerajaan Makassar (Gowa-Tallo), menjadi periode paling menyita perhatian penelitian dan penulisan sejarah. Pasca periode itu tradisi literasi masyarakat di Sulawesi Selatan mengalami kemunduran. Dalam tinjauan historiografi pasca kejatuhan Makassar, terutama abad ke-18 dan abad ke-19 juga belum banyak mendapat perhatian.

Dalam konteks kekinian, beberapa tahun belakangan ini, muncul animo yang besar oleh berbagai kalangan terhadap literasi. Tumbuhnya kegairahan tersebut salah satunya ditopang oleh kebanggan literasi wilayah ini di masa lampau. Di luar birokrasi negara, tumbuh semangat terutama pada kalangan muda untuk terlibat dan menggangas gerakan (budaya) literasi dalam berbagai bentuk. Di Sulawesi Selatan, hal ini menjadi momentum tersendiri, setelah dalam masa panjang tidak memperlihatkan geliat literasi yang menonjol. Berdiri pula berbagai komunitas dengan berbagai kegiatan pengembangan budaya literasi, baik di Kota Makassar maupun di tempat lain di Sulawesi Selatan.

Berdasar tinjauan umum pada periode yang panjang tersebut, tulisan ini akan mengeksplorasi bagaimana keterkaitan antara kejayaan Kerajaan Makassar, perkembangan tradisi literasi, dan historiografi atas Sulawesi Selatan. Keterkaitan antara berbagai aspek tersebut akan memperlihatkan seperti apa kontinuitas dan keterputusan dalam narasi sejarah Sulawesi Selatan. Di pihak lain bagaimana "romantisme" sejarah masa lampau selalu bisa dipergunakan untuk membangun narasi kekinian. Dalam konteks ini, argument Cumming bisa ditinjau yang menyatakan bahwa orang Sulawesi Selatan gandrung melihat masa lalunya ketika menatap masa depannya. Disebutkannya bahwa orang Sulawesi Selatan melihat masa lalu sebagai bagian yang bersemangat dan vital dari kehidupan mereka (Cummings, 2015: 5, 74). Makassar dalam tulisan ini merujuk pada Kerajaan Makassar (Gowa-Tallo) pada abad ke-16 dan ke-17, dan Sulawesi Selatan merujuk pada kesatuan wilayah administratif yang kini disebut propinsi dengan ibukota Makassar. Pada masa lampau Sulawesi Selatan menjadi wilayah geografis Kerajaan Makassar. 


\section{Tradisi Literasi Dalam Masyarakat Sulawesi Selatan}

Secara umum, kata literasi dikaitkan dengan kegiatan membaca dan menulis. Menurut Richard Kern, literasi adalah sesuatu yang kompleks dan bersifat dinamis, atau sesuatu yang lebih dari kemampuan membaca dan menulis dengan penggunaan praktik-praktik situasi sosial dan historis, serta kultural dalam menciptakan dan menginterpretasikan makna melalui teks (Kern, 2000). Pengertian tersebut sejalan dengan gerakan literasi saat ini, yang selain menggairahkan budaya membaca dan menulis, juga mendorong langkah dalam menemukan ide-ide dari setiap hal yang dibaca.

Sulawesi Selatan dalam teritori kebudayaan, punya tradisi panjang literasi. Kekayaan literasi terutama dapat diwariskan dan bertahan karena adanya aksara lontaraq. Lontaraq berasal dari kata "lontar" yaitu sejenis pohon yang banyak tumbuh di Sulawesi Selatan. Konon, bentuk aksara Lontaraq terinspirasi oleh "sulapa eppa wala suji", semacam pagar bambu dalam acara ritual yang berbentuk belah ketupat. Sulapa eppa (empat sisi) adalah bentuk mistis kepercayaan kuno yang menyimbolkan unsur pembentukan manusia, yaitu api, air, angin, dan tanah. Makna berbeda diartikan sebagai empat arah mata angin. Naskah ditulis menggunakan lidi atau kalam yang terbuat dari ijuk kasar. Ditulis di atas selembar daun lontar yang panjang dan tipis yang digulung pada dua buah poros kayu sebagaimana halnya pita rekaman. Memuat tentang tata aturan pemerintahan dan kehidupan masyarakat, dalam bentuk dokumen, peta, hukum perdagangan, surat perjanjian, hingga buku harian.

Dalam memajukan tradisi literasi, maka hampir di setiap kerajaan di Sulawesi Selatan, ditunjuk penulis istana yang ditugaskan mencatat segala urusan administrasi, dan aktivitas masyarakat dalam kerajaan tersebut. Di antaranya adalah perjanjian politik, pernyataan perang, surat perdamaian, wilayah kerajaan, kekayaan negara, aktivitas perdagangan, ritual keagamaan,
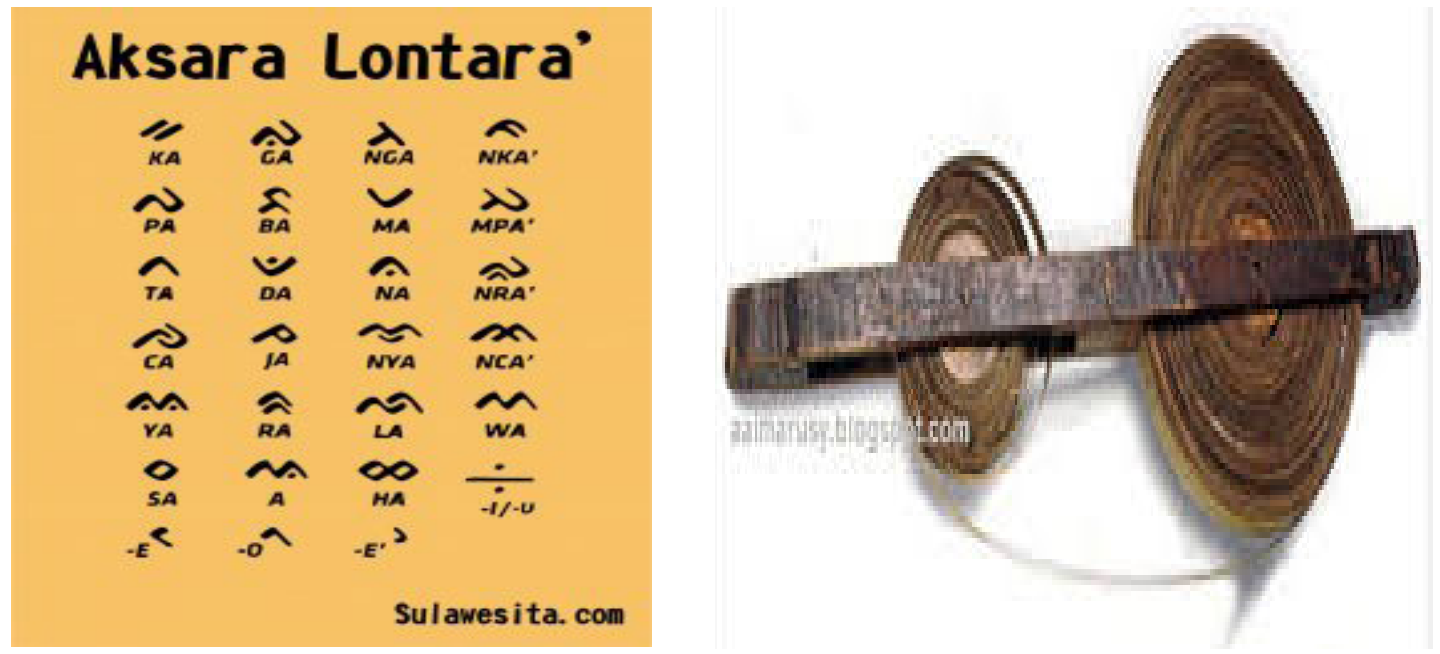

Figur 1. Huruf dalam Aksar Lontaraq (kiri), dan Media Penyimpanan Naskah Lontaraq (kanan). Sumber: http:// sulawesita.com dan aaimarusu.blogspot.com 
upacara kenegaraan, silsilah, dan catatan harian raja. Pada masa kolonial Belanda, tradisi penulisan aktivitas politik dan masyarakat tetap dicatat, baik pada kerajaan-kerjaan utama, maupun oleh kerajaan-kerajaan kecil (kerajaan bawahan), yang dikenal sebagai Lontaraq Akkarungeng. Namun secara perlahan penggunaan aksara Lontaraq tergerus dengan penggunaan aksara latin yang digunakan secara luas. Terlebih sejak awal abad ke-20, ketika sekolah pemerintah, maupun sekolah swasta dibuka. Pasca kemerdekaan, pelajaran aksara Lontara tetap di pelajari di sekolah, namun aksara tersebut tidak lagi menjadi tradisi dalam mencatat peristiwa politik, serta aktifitas penduduk atau masyarakat.

Huruf lontaraq berhasil mendokumentasikan sejarah dan nilai budaya masyarakat Sulawesi Selatan. Salah satu karya agung yang lahir dari aksara ini adalah naskah La Galigo. Sebuah epic mitos penciptaan dari peradaban Sulawesi Selatan, yang ditulis antara abad ke-13 dan ke-15 dalam bentuk puisi berbahasa Bugis kuno dan huruf Lontara kuno. Selain menceritakan kisah asal usul manusia, juga berisi almanak sehari-hari, dan terutama bercerita tentang kebudayaan di Sulawesi Selatan sebelum abad ke-14. Epic ini berkembang sebagian besar melalui tradisi lisan dan dinyanyikan pada kegiatan tradisi. Versi tertulis hikayat ini berhasil dikumpulkan sebanyak 6000 halaman atau 300.000 baris teks. Naskah ini disusun kembali setelah Benjamin Frederick Matthes, seorang misionaris menyalin dari penduduk di Sulawesi Selatan sekitar 23 tahun lamanya pada abad ke-19. Usaha Matthes dalam mengumpulkan naskah La Galigo dibantu oleh seorang putri Raja Tanete bernama Colliq Pujie. Sebagian besar naskah tersimpan di perpustakaan KITLV di Belanda. Hikayat ini semakin dikenal khalayak internasional, setelah diadaptasi dalam pertunjukan teater I La Galigo oleh Robert Wilson, sutradara asal Amerika Serikat, yang mulai dipertunjukkan secara internasional sejak tahun 2004. Salah seorang tokoh yang berjasa dalam melakukan transliterasi naskah ini adalah Muhammad Salim. Kajian atas naskah ini juga ditekuni oleh Nurhayati Rahman.
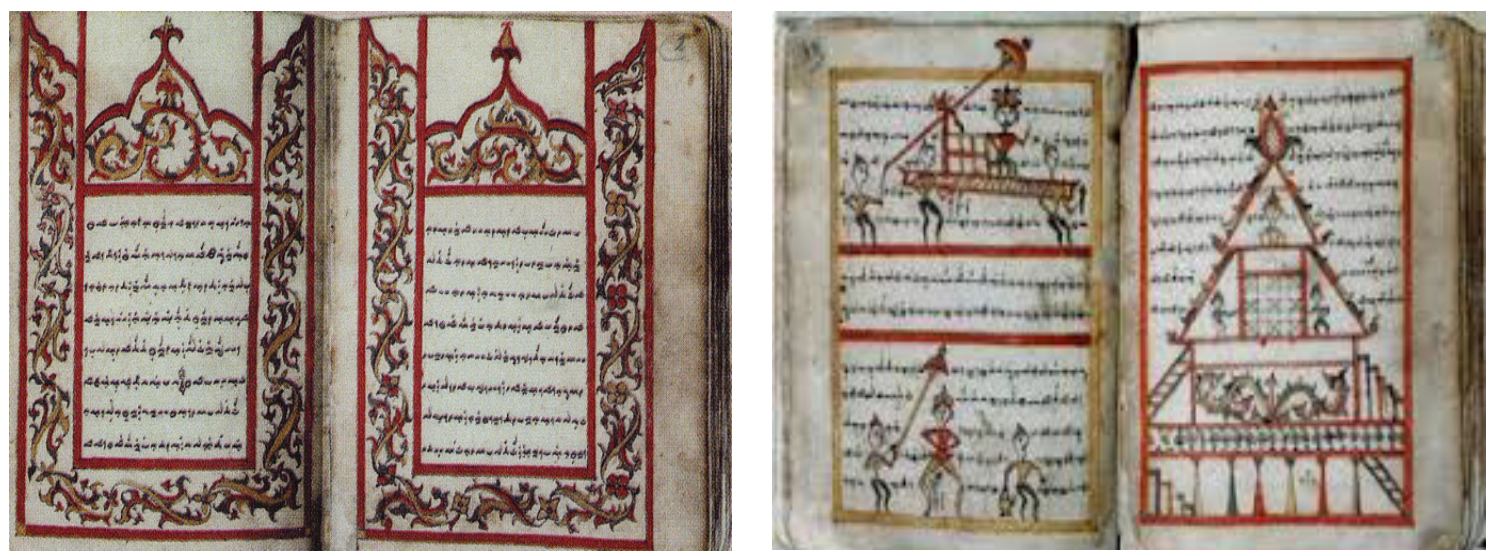

Figur 2. Naskah La Galigo. Sumber: www.http:/wordpress.com/lagaligo-epos 


\section{Kemunculan Makassar: Dari Mitologi ke Entitas Politik}

Sejarah Sulawesi Selatan dihubungkan dengan kebesaran tradisi maritim, kekayaan literasi, kompleksitas kekuatan politik, perompak yang menakutkan, dan beragam peran tidak saja di tingkat lokal, namun juga dalam jaringan perdagangan di Nusantara, Asia Tenggara bahkan global. Warisan peradaban Bugis-Makassar lahir dan berkembang dalam persilangan tradisi lokal, hubungan dengan Asia Tenggara serta jaringan internasional.

Masa lalu Sulawesi Selatan adalah transformasi ide dan realitas sejarah yang terus diciptakan. Sulit memisahkan narasi arkeologis, mitologis dan historis dalam setiap tahapan perkembangan peradabannya. Meskipun demikian, suatu tradisi lama yang diagungkan, kadang tidak pernah benarbenar menjadi bagian dari suatu realita yang tercipta. Kehadirannya tidak lebih dari romantisme atas kebesaran masa lalu. Apa yang terjadi pada masa yang belakangan adalah sesuatu yang sesungguhnya berbeda dan digerakkan oleh semangat yang berbeda pula. Meski demikian, Sejarah Sulawesi Selatan, selalu menjadi bagian dari penciptaan identitas dan untuk tujuan berbagai kepentingan dari waktu ke waktu. Sekumpulan ide dan pengetahuan masa lalu acap kali menjadi modal penciptaan masa kini, bahkan ketika merumuskan masa depan. ${ }^{1}$

Salah satu hal yang tidak jelas, kabur, dan sering dikacaukan dalam narasi sejarah Sulawesi Selatan adalah tentang penyebutan Makassar yang bercampur dalam berbagai kategori; entitas politik, etnis/antropologis, maupun unit geografis. Selain itu, Makassar acapkali tidak mampu dibedakan dan dijelaskan secara kronologis dengan keberadaan Kerajaan Gowa dan Tallo.

Menurut Kitab Negarakretagama (pupuh XIII dan XIV), Makassar adalah sebuah nama wilayah di sebelah timur Jawa yang merupakan kekuasaan Majapahit pada pertengahan abad ke-14 (Slametmulyana, 1979: 146; Kern, 1919; Brandes, 1920: 2009). Akan tetapi, hingga periode ini, Makassar belum dikenal sebagai nama kota ataupun nama kerajaan. Kata Makassar hanya merujuk kepada suatu kelompok etnis/suku, dengan penyebutan 'orang Makassar', yang memiliki bahasa sendiri, dan mendiami pesisir selatan, meliputi daerah Gowa, Takalar, Jeneponto, Bantaeng, sebagian Bulukumba, sebagian Maros dan sebagian Pangkajene Kepulauan (Pires, 2016; Mattulada, 2011: 17-18).

Munculnya entitas politik, mendasari lahirnya ruang perkotaan atau ibukota. Di Sulawesi Selatan, entitas politik awal ditandai dengan

1) Pemerintah Kota Makassar di awal abad XXI, mengampanyekan slogan "Makassar kota dunia”, yang dilandasi romantisme kebesaran masa lalu Makassar. Argumen senada dilontarkan beberapa budayawan ketika mendesak pengembalian nama Kota Makassar yang antara tahun 1971-1998 bernama Ujung Pandang. Lihat F.Majid dan J.Mappanganro, Makassar. Bagaimana Menjadi Kota Dunia? (Yogyakarta: Ombak, 2009). 


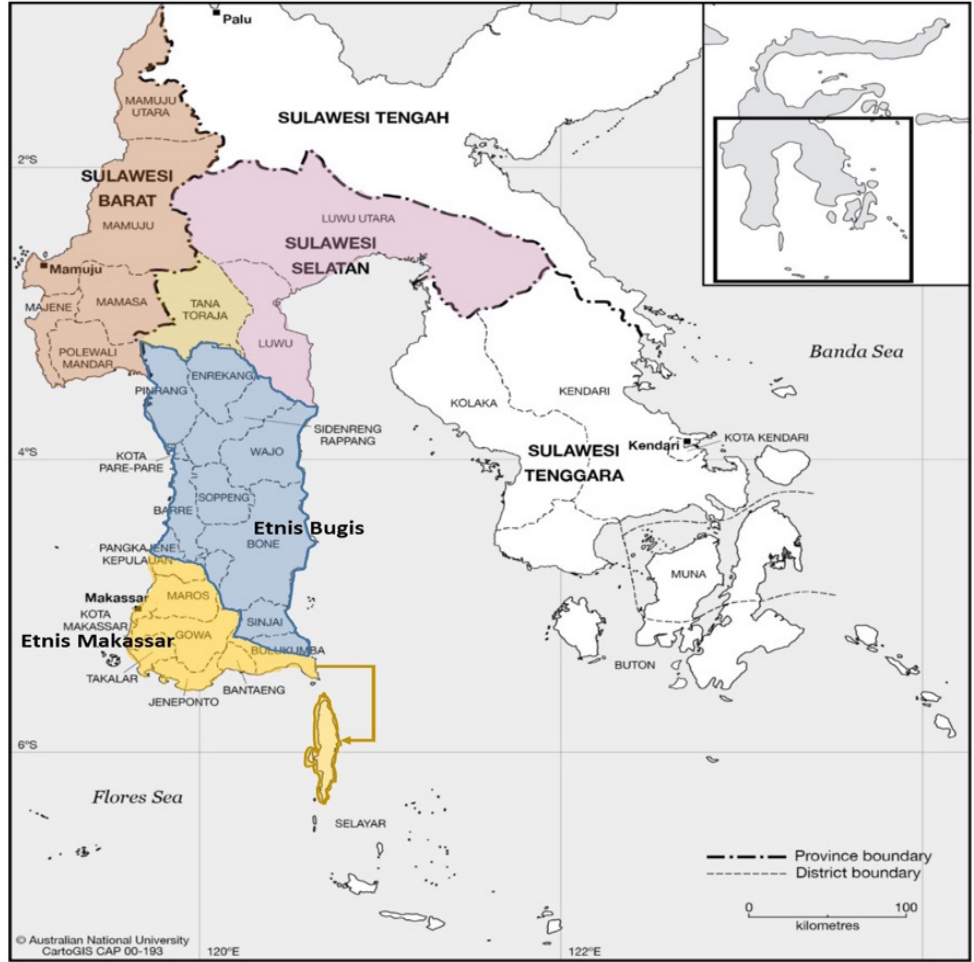

Figur 3. Peta Wilayah Berbasis Etnis Makassar. Sumber: http://asiapacific. anu.edu.au/mapsonline/base-maps terbentuknya ikatan politik kecil/komunitas lokal (bori, wanua), yang dipersatukan dengan lahirnya mitos tumanurung ${ }^{2}$ dan disertai gaukang/kalompoang ${ }^{3}$. Mitologi tumanurung oleh kaum bangsawan dijadikan dasar argumen adanya "hak yang didapat dari Tuhan" untuk memerintah dan pembenaran atas kedudukan istimewanya (Harvey, 1989: 20; Patunru, 1993: 139-141). Di sisi lain, benda-benda sakral (gaukang) menjadi peletak terbentuknya komunitas dan kedaulatan (sovereignity), serta sebagai representasi kekuasaan politik dan simbol pemersatu suatu kelompok. Keberadaan suatu kesatuan komunitas (paqrasangang) disertai berkembangnya sistem pranata religi, sosial, dan politik (Rossler, dalam Tol, Dick, Acciaioli, 2009: 220; Andaya, 2004: 11-15; Poelinggomang, 2004: 25; Republik Indonesia, Propinsi Sulawesi, 1953: 41; Mattulada, 1985: 370-277; Bosra, 2008: 47-48; Koerts, dalam van der Wal (peny.), 2001: 5556; Macknigt, 1993: 41).

Berdasar lontara' Patturiolong Tugowa-ya (sejarah orang Gowa) sekitar tahun 1300 Masehi di semenanjung selatan Pulau Sulawesi, tepatnya di Takak Bassia wilayah Gowa, turun dari kayangan seorang perempuan yang dipercaya sebagai tumanurung. Saat itu kesatuan politik kecil yang berjumlah 'sembilan negeri/ bendera/ pengabdi' (bate/kasuwiyang salapang) bersatu dan sepakat mengangkatnya sebagai pemimpin (Patunru, 1993; Mattulada, 1998: 30-38). Tumanurung kemudian dinikahkan dengan Karaeng Bayo (penguasa samudera), tokoh yang punya hubungan dengan kerajaan kuat di seberang

2) Tumanurung adalah sosok manusia dari dunia lain yang dianggap turunan dewa, biasanya turun dari langit, bisa laki-laki maupun perempuan. Rakyat setempat yang terpecah-belah kemudian meminta agar makhluk eksotik ini bersedia menjadi penguasa mereka.

3) Gaukang (disebut juga kalompoang atau arajang) dipercaya sebagai peninggalan (pusaka) tumanurung yang akan menjaga atau menjamin keberlangsungan suatu dinasti. Di Gowa, benda pusaka tersebut di antaranya berupa rantai emas (tanisamanga), pedang sudanga. Gaukang dapat juga berupa bendera, manuskrip, perhiasan, senjata perang, cincin, payung, dan lain-lain. Adakalanya terbuat dari batu, kayu, emas, perak ataupun sutera. 
lautan dan memiliki keahlian maritim. ${ }^{4}$ Dari pernikahan ini lahir keturunan yang kemudian menjadi raja-raja Gowa, sekaligus mengukuhkan berdirinya satu kekuasaan politik bernama Kerajaan Gowa (Gibson, 2009: 154, 167; Caldwell, 1995: 403).

Ibukota Kerajaan Gowa dibangun di tempat turunnya tumanurung, sekaligus menjadi kediaman raja dan tempat menyimpan gaukang. Istana raja dibangun dan dinamai "Tamalate" (tidak layu) karena daun dari kayu yang dijadikan tiang istana belum layu sewaktu istana selesai dibangun. Tamalate kemudian lebih dikenal sebagai nama tempat, dimana ibukota pertama Kerajaan Gowa berada. Di sekelilingnya tumbuh puluhan perkampungan baik di daerah Tamalate, dan Bontobiraeng. Keberadaan gaukang menjadi pendorong sekaligus simpul tumbuhnya masyarakat tersebut. Ibukota dari sebuah kerajaan berbentuk konfederasi itu kemudian dinamai 'Kale Gowa”, yang sekaligus menjadi pusat pemerintahan dan ritual keagamaan. Letaknya berada di wilayah pedalaman dan berorientasi agraris dan tidak terhubung langsung dengan lautan luas dan tradisi bahari (lihat lingkaran 1 pada Gambar 4) (Wolhoff dan Abdurrahim, 1959; Reid, 2004: 133; Rahim, 2011: 45.). Dari segi waktu, Anthony Reid menyatakan bahwa karena generasi awal dinasti Gowa dikenal hanya sekedar nama, maka tidak punya cukup dasar untuk menempatkan perintisan dinasti ini lebih awal dari tahun 1400 Masehi (Reid, 2004: 132).

Menjelang akhir abad ke-15, konsolidasi internal untuk menghimpun pusat-pusat kekuasaan kecil berhasil diwujudkan, dengan Gowa sebagai kerajaan utama yang beribukota di Kale Gowa. ${ }^{5}$ Kerajaan Gowa telah memiliki wilayah kekuasaan yang jelas, sistem pemerintahan, ibukota kerajaan, dan kontak dengan pusat perniagaan di Jawa. Dengan demikian, Kerajaan Gowa sudah mempunyai modal yang cukup untuk menjadi salah satu kekuatan utama di Asia Tenggara dalam aktivitas niaga pada masa selanjutnya. Hingga periode ini, Makassar dikenal masih sebatas sebagai suku bangsa/etnis (antropologis) yang mendiami suatu wilayah, yang penduduknya memiliki budaya tersendiri. Terkait dengan keberadaan Kerajaan Gowa yang berpusat di Kale Gowa, M.C. Ricklefs menyebutkan bahwa kerajaan klasik ini menjadi peletak dasar negara pada periode modern awal yang ditemui orang Barat ketika pertama kali tiba (Ricklefs, dkk., 2013: 97).

4) Pangeran yang menikahi tumanurung disebut berasal dari Bantaeng. Suatu daerah di pesisir selatan Sulawesi yang konon sudah melakukan kontak dengan daerah Jawa dan wilayah lainnya di Nusantara. Kemampuan tokoh (manusia) pria untuk menikahi seorang perempuan dewa merupakan mitos pantai yang mengindikasikan adanya hubungan penguasa di Sulawesi Selatan dengan Kerajaan Majapahit pada abad ke-14.

5) Sebagai perbandingan, wilayah lain di Sulawesi Selatan juga telah melahirkan kerajaan utama. Wilayah Bugis melahirkan Kerajaan Bone (ibukota di Watangpone), Kerajaan Soppeng (ibukota di Watangsoppeng), dan Kerajaan Wajo (ibukota di Tosora). 


\section{Kekuatan Literasi dan Kejayaan Kerajaan Makassar}

Pada awal abad ke-16, Kerajaan Gowa menyambut kedatangan "dunia baru” dengan memindahkan ibukota yang lama di Kale Gowa ke daerah pesisir di dekat muara sungai Jenneberang (Garassi') (Wolhoff dan Abdurrahim, 1959: 18; Mattulada, 2011: 7-9). ${ }^{6}$ Pemindahan ibukota adalah langkah cerdik melihat adanya kesempatan untuk terlibat dalam hirup pikuk perniagaan di Asia Tenggara. Ibukota itu diberi nama Somba Opu yang dibangun dengan orientasi maritim dan pelayaran jarak jauh, serta sebagai pusat konsolidasi kekuatan politik lokal. Salah satu konsolidasi kekuasaan terpenting adalah menyatunya Kerajaan Gowa dan Kerajaan Tallo. ${ }^{7}$ Pada saat bersamaan, muncul pula para pemimpin dengan bakat istimewa sebagai manusia-manusia perintis ke arah kemajuan. Dengan demikian, era Somba Opu pada abad ke-16 dan ke-17, layak dianggap era modern awal, yang ditopang dengan berkembangnya tradisi literasi. ${ }^{8}$

Letak Somba Opu strategis karena sebagai ruang laut yang merangkai pulau dan daratan di barat ke timur dan utara ke selatan. ${ }^{9}$ Dasar morfologis kota, pada awalnya hanya di sekitar Benteng Somba Opu dan muara Sungai Jeneberang. Namun setelah menyatunya Gowa dan Tallo sebagai kerajaan kembar, maka ruang kota terbentang antara istana raja Gowa di muara Sungai Jeneberang dan istana raja Tallo di muara Sungai Tallo. Kedua muara sungai tersebut juga dihubungkan oleh figurasi benteng-benteng yang terletak di pesisir laut seperti yang tercakup dalam lingkaran 2 dan 2a pada Gambar 4. Sejak saat ini, Kerajaan Gowa-Tallo mulai terlibat dalam perdagangan jarak jauh yang menyebabkan banyak pedagang dan orang asing berdatangan (Skinner (ed.), 2008: 2; Reid, 2003: 151,153).

Bersatunya Kerajaan Gowa-Tallo dan keterlibatannya pada

6) Tuma'parri'si' Kallonna (berkuasa: 1512-1548) adalah raja Gowa ke-9 yang memindahkan ibukota kerajaan, dan peletak dasar perubahan serta kemajuan Kerajaan Gowa.

7) Berdasar sumber lontaraq, sejak masa raja Gowa ke-6 Tunatangkak Lopi, Kerajaan Gowa sudah terlibat perselisihan dengan Kerajaan Tallo. Pada Pemerintahan Raja Gowa ke-9 Tumaparrisi' Kallonna, peperangan Gowa dan Tallo diakhiri dengan perjanjian perdamaian dengan menyatukan kedua kerajaan tersebut sehingga dikenal sebagai Kerajaan Gowa-Tallo. Ditetapkan bahwa siapa saja pewaris takhta Gowa akan menjadi raja, dan pewaris takhta Tallo menjadi mangkubumi (perdana menteri).

8) Bandingkan dengan konstruksi era modern Indonesia yang disusun Sartono Kartodirdjo, Pengantar Sejarah Indonesia Baru: 1500-1900. Dari Emporium sampai Imperium (Jakarta: Gramedia, 1992).

9) Menurut A.B. Lapian, pelayaran dari luar ke Bandar Makassar melaui tiga arah. Pertama, dari sebelah utara; dari Laut Cina Selatan lewat Laut Sulu dan Laut Sulawesi. Kedua, jalan dari sebelah timur; Laut Maluku, Laut Banda, bahkan dari Samudera Pasifik. Jalur ini menghubungkan pula wilayah di bagian selatan dan timur seperti Bali, Flores hingga ke Australia. Ketiga, pintu masuk dari barat; menghubungkan Laut Jawa dengan Pulau Jawa dan Sumatera. Lihat A.B. Lapian, Orang Laut, Bajak Laut, Raja Laut. Sejarah Kawasan Laut Sulawesi Abad XIX. (Jakarta: Komunitas Bambu, 2009), hlm.33. 
perdagangan internasional, membawa konsekuensi pada penyebutan entitas ini. Pertama, Kerajaan Gowa-Tallo kemudian sering disebut pula sebagai Kerajaan Makassar, terutama di kalangan penjelajah bangsa Barat maupun para pedagang di Asia Tenggara. Kedua, bentang kota tidak hanya berada di sekitar Benteng Somba Opu, tetapi memanjang sepanjang pantai, dan disebut dengan Bandar Makassar atau Kota Makassar. Luasnya wilayah kota dan pemukiman yang terpisah-pisah, menyebabkan sulit mengenali pusat atau batas perkotaan. Seperti

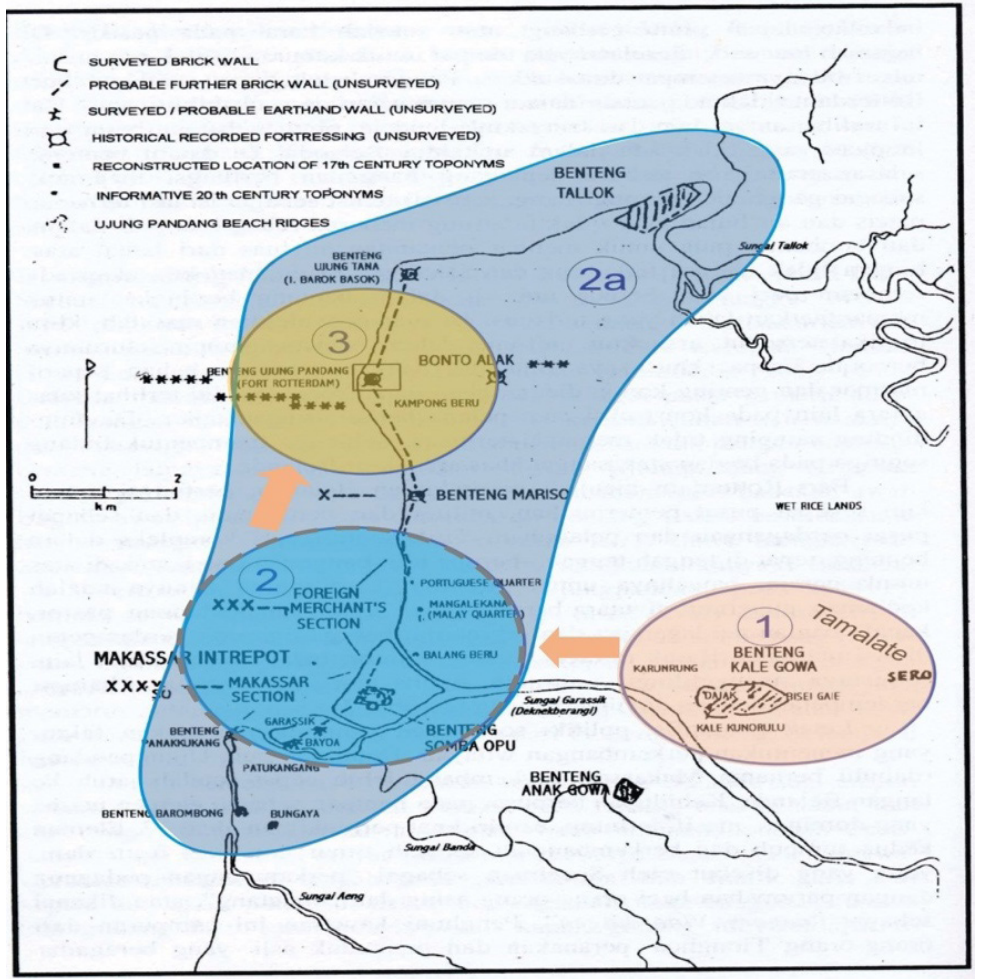

Figur 4. Peta Benteng Somba Opu (pusat) dan Beberapa Benteng di Pesisir yang Merupakan Bandar (Kota) Makassar. Sumber: Diolah dari Yulianto Sumalyo (1999). dalam penjelasan Anthony Reid bahwa orang hampir tidak bisa mengenali mana pusat sebagai kota. Kota tampak kehija-hijauan dan hampir tidak ada batas antara kota dan pedesaan (Reid, 1980: 240). Ruang kota yang dimaksud adalah kumpulan desa yang menyerupai negara kota (urban state) meliputi pemukiman yang luas. Sejak saat ini, Makassar menjadi termasyhur baik sebagai nama kerajaan maupun sebagai nama kota / ibukota kerajaan. Bandar (kota) Makassar yang luas tersebut konon dihuni penduduk yang mencapai 100.000 orang dari bermacam-macam kebangsaan, sehingga memungkinkan berlangsungnya pertemuan dan juga perluasan ide-ide baru hasil persilangan kebudayaan.

Kerajaan Makassar selanjutnya beralih dari satu keberhasilan kepada keberhasilan lain, tidak hanya dalam soal perluasan wilayah, tetapi juga dalam inovasi teknik dan intelektual. Beberapa raja yang berkuasa pada abad ke-16, seperti Tunipalangga (1546-1565) dan Tunijallo (1565-1590) menghasilkan karya dan kebijakan penting, antara lain; menunjuk penulis istana, pembuatan senjata perang dengan bubuk mesiu, hubungan diplomatik luar negeri, penggunaan batu-bata, pencampuran emas dengan logam, pemakaian sistem timbangan dan ukuran, serta mobilisasi aneka pengrajin dalam serikat sekerja.

Munculnya Makassar dengan cepat dan mengesankan pada abad ke-16 dan berlanjut di abad ke-17, oleh Anthony Reid dijelaskan dalam perspektif perdagangan sebagai kekuatan penentu. Menurutnya transformasi ekonomi 
merupakan substruktur yang menggerakkan peristiwa dan perubahan di periode tersebut. Pada era ini untuk pertama kalinya dunia secara fisik dipersatukan oleh terbukanya jalur-jalur perdagangan langsung antara Eropa dengan bagian-bagian dunia lainnya (Lapian, 2009); Mattulada, 2011: 28; Vlekke, 1943: 108; Miller, 2012: 25). ${ }^{10}$ Karena perdagangan pula, lahir para pemimpin dengan bakat istimewa dalam mengadopsi pemikiran dan teknologi baru. Salah satu kunci keberhasilan bandar niaga ini karena orang Makassar memperlakukan sama semua pedagang asing dari seluruh penjuru dunia (Reid, 2009: 79-82; Reid, 2004: 1,10,14,155).

Pada abad ke-17, posisi Kerajaan Makassar semakin kuat khususnya sejak tahun 1605, saat agama Islam diterima di kerajaan ini. Masa pemerintahan Sultan Alauddin (1593-1639) dengan Mangkubumi (perdana Menteri) Karaeng Matoaya (1593-1610) menandai puncak kejayaan Makassar. Penaklukan dengan dalih "perang Islam" dan kemampuan diplomasi Karaeng Matoaya mampu menundukkan seluruh wilayah Sulawesi Selatan, dan memperluas wilayah kekuasaan hingga pantai timur Borneo, Sunda Kecil, Buton, Sumbawa, Lombok, dan Kepulauan Aru-Kei. Di bawah kepemimpinan keduanya, Makassar menjadi pasar utama di Asia Tenggara untuk rempahrempah Maluku. Makassar juga menjadi pembela terdepan kebijakan pintu terbuka dan perdagangan bebas yang ingin dihancurkan VOC. Selama periode ini, Kota Makassar tumbuh sangat pesat dari segi ukuran dan kecanggihan (Ricklefs, dkk., 2013: 250-252; Reid, 2004: 172,183; Vlekke, 1943: 12).

Armada kapal Kerajaan Makassar berkembang sampai titik dimana mampu mengirim ekspedisi lebih dari seribu kapal, sehingga pengaruh politiknya pun ikut melambung. Hingga tahun 1590, struktur organisasi kerajaan Makassar yang lengkap sudah rampung dengan birokrasi yang terspesialisasi secara fungsional. Terdiri atas lembaga komersial dan finansial yang rumit dan undang-undang tertulis, bengkel-bengkel dengan pekerja permanen, proyek-proyek kerja perbudakan berskala besar, pasukan siap pakai lengkap dengan teknologi mesiu. Terbentuk pula suatu sistem norma, hukum, dan aturan yang menjadi landasan kehidupan bernegara dan bermasyarakat yang dikenal dengan sistem panggaderreng/ pangngadakkang, berupa; ada', rapang, bicara, dan wari, yang dilengkapi dengan sara' (syariat Islam) setelah Islam datang (Reid, 2004: 183,189,191; Gibson, 2009: 202,205; PaEni (ed.), 1986: 17).

Generasi selanjutnya terus mempertahankan capaian itu, ketika Sultan Malikussaid menjadi raja (1639-1653) dan Karaeng Pattingalloang sebagai

10) Pedagang asing yang rutin datang di Bandar Makassar pada abad ke-16 dan ke-17, di antaranya; orang Portugis (sejak 1538), Melayu (1540), dan Belanda 1601. Inggris dan Denmark mendirikan kantor dagang tahun 1613, Spanyol (1615), Cina (1619), Perancis (1622), dan Golconda/India Selatan (1650). Kapal dagang juga datang dari Siam, Kamboja, Pahang, Patani, Campa, Minangkabau, Johor, dan Portugal. Pada 1641, saat Malaka jatuh ke tangan Belanda, maka sekitar tiga ribu orang Portugis menetap di Makassar. 
mangkubumi (perdana menteri). Mangkubumi Pattingalloang terkenal karena kecakapan intelektual dan ketertarikannya pada ilmu pengetahuan. Hal tersebut diwujudkan dengan mendirikan perpustakaan dengan koleksi buku berbagai bahasa, peta, bola dunia, bahkan memesan teropong bintang. Karyanya yang lain adalah penerjemahan buku, penyusunan peta pelayaran, teknologi militer, dan penulisan sejarah/kronik. Pattingalloang menyerupai insan pelaku renaisans Eropa dengan menjadi manusia pemikir sekaligus pelaku dan terobsesi dengan kemajuan ilmu pengetahuan (Reid, 2004: 197199; Reid, 2009: 79-80; Miller, 2012: 26). Era ini menandai lahirnya para cendekiawan terkemuka tidak saja di ibukota Makassar, tetapi juga pada wilayah lain di Sulawesi Selatan. ${ }^{11}$

Bandar niaga yang ramai mendorong terbangunnya pemukiman perkotaan. Di sekitar Benteng Somba Opu, berdiri perkampungan luas yang dikenal dengan Mangngallekana yang diperuntukkan untuk para pedagang dari luar. Perkampungan lain tersebar hingga ke Benteng Ujung Pandang di utara, dan Benteng Panakukkang di selatan. Aktivitas sosial, keagamaan dan kebudayaan berkembang tidak hanya di pusat kota di Somba Opu, tetapi hingga di perkampungan, seperti di Kampung Bontoala' (lihat Gambar 2.2).

Berbeda dengan Anthony Reid yang melihat dominannya faktor perdagangan, ditunjang dengan kemampuan dalam mengadopsi ide dan pengetahuan dari interaksi abad niaga ini dalam kemajuan Makassar. William Cummings justru melihat kemampuan para elit kerajaan dalam merekonstruksi kembali masa lalunya untuk kepentingan zamannya sebagai faktor utama. "Signifikansi nilai budaya" dimunculkan dengan menempatkan Gowa sebagai patokan atau pusat alamiah dunia Makassar. Mengikuti Clifford Geertz yang menelurkan istilah 'pusat keteladanan' untuk memaparkan bagaimana istana-istana Asia Tenggara menggunakan ritual dan upacara dalam sebuah tindakan membentuk diri sendiri yang bersifat kosmologis dimana mereka membangun kesan di hadapan rakyatnya sebagai pusat masyarakat (Geertz, 1980).

Cummings melihat bahwa tradisi literasi dan manipulasi sejarah tertulis menawarkan kepada Gowa sebuah kesempatan besar untuk membentuk kembali cara bagaimana orang Makassar memandang landskap politik dan budaya mereka. Ada tiga hal terkait soal ini; pertama, Gowa berusaha mengendalikan bagaimana masa lalu diinterpretasi dan diingat dalam komunitas Makassar lainnya, terutama melalui benda-benda sakral sebagai penjelmaan masa lalu, dan usaha ini memiliki konsekuensi politik. Kedua,

11) Pada abad ke-16 dan ke-17, di wilayah Bugis muncul para pemikir terkemuka. Di antaranya Kajao Laliddong, seorang diplomat ulung kerajaan Bone yang menyusun strategi diplomasi yang termasyhur. Selain itu ada Puang Rimagalatung yang menghasilkan karya paupaurikadong, semacam cerita rakyat yang menyimpan perbendaharaan pengetahuan dan nilai-nilai budaya orang Bugis. Di Kerajaan Wajo terkenal para matoa yang menyusun sistem pemerintahan demokratis. 
penyebaran sejarah tertulis keluar Gowa, mendorong orang Makassar dimana pun memandang Gowa sebagai tolok ukur bagi sejarah komunitasnya. Ketiga, kemampuan Gowa dalam mengarahkan praktik agama Islam di wilayah Makassar, dan termasuk interpretasi historis atas asal-muasal Islam di Sulawesi Selatan, memberikan kontribusi pada persepsi bahwa Gowa adalah pusat keteladanan di Sulawesi Selatan (Cummings, 2015: 191-192).

Konsep "penciptaan sejarah" diungkapkan untuk menjelaskan bagaimana orang (elit) Makassar membuat jenis sejarah baru yang melayani tujuan yang baru. Kronik, genealogi, daftar raja-raja, perjanjian, catatan harian, kode hukum, dan nasihat memerintah banyak bermunculan pada abad ke-16. Semuanya menjembatani masa lalu ke masa kini dengan cara-cara yang tak dikenal sebelumnya. Aspek prasejarah dan mitologi ditampilkan karena hal itu dijadikan dasar penciptaan sejarah di awal era modern. Keterbukaan dan juga pluralisme bukanlah produk atau hasil interaksi era perdagangan, namun itu terbangun dari tradisi lokal tumanurung yang mendudukkan kalompoang sebagai sumber kekuasaan, serta melalui perjanjian yang mengakui hak pihak lain (Cummings, 2015).

Hingga pertengahan abad ke-17, pengaruh Kerajaan Makassar meluas tidak saja di Indonesia bagian timur namun hingga Sulu dan Magindanao (Warren, 1981). Makassar tidak saja tumbuh sebagai bandar penting, namun juga terlibat dalam memperebutkan jalur-jalur perdagangan dan kekuasaan di Nusantara bahkan Asia Tenggara. Makassar menjelma sebagai kota dunia yang sesungguhnya dengan kekuatan kosmopolitannya. Kesuksesan yang semakin hari tidak disenangi oleh pihak VOC (Lapian 2009: 69; Boxer, 1983: $37)$.

Kemunduran Makassar mulai terlihat sejak meninggalnya Mangkubumi Karaeng Pattingalloang pada tahun 1654. Terjadi pemusatan kekuasaan yang tidak memiliki batasan kuasa yang jelas. Di samping itu, muncul pertikaian di kalangan elit penguasa, pemberontakan musiman orang Bugis, serta berbagai tindak sewenang-wenang penguasa sehingga merusak daya tarik Bandar Makassar bagi pedagang. Makassar tetap merupakan sebuah kota besar sampai dengan penaklukan oleh Belanda (1660-1669), tetapi kota ini sudah tidak lagi memiliki kesatuan dan wawasan dalam menghadapi berbagai ancaman yang ada.

Era Somba Opu menyisakan kenangan, satu babakan penting dimana sebuah kota dagang mencapai puncak kejayaan, saat orang Eropa datang sebagai saudagar dan mitra yang sejajar. Ada banyak warisan dari periode ini, di antaranya: kronik sejarah (patturiolong), traktat (ulukana), sumpah (tunra sapatta atau sumpa), kitab adat (rapang/rapang bicara), peraturan sosial (parakara), pernyataan perang (timu-timu bunduq), catatan harian (lontaraq bilang), dan silsilah keturunan. Semuanya memiliki kemampuan untuk melestarikan kata dan tindakan dari masa lalu. 
Tidak berlebihan, jika periode sejak awal abad ke-16 hingga menjelang akhir abad ke-17 merupakan masa-masa perkembangan modernitas dalam arti luas. Merujuk catatan Cummings yang menyebut bahwa penguasa Makassar di abad ke-16 dalam pencapaiannya sering kali menyebut kata; "pertumbuhan", "kenaikan”, "perluasan”, dan "kemajuan”. Kerajaan ini bertransformasi dari kekuasaan kecil menjadi kekuasaan paling dominan di semenanjung Sulawesi. Para penguasa Makassar mengubah awal yang tidak menjanjikan menjadi kisah yang mengesankan. Anthony Reid menyebutnya sebagai "salah satu cerita sukses paling cepat dan spektakuler sepanjang sejarah Indonesia" (Reid, 1983: 117).

\section{Gerakan Literasi dan Historiografi Sulawesi Selatan}

Gerakan literasi di Indonesia hadir sebagai respons atas keprihatinan rendahnya budaya literasi di tengah masyarakat. Gerakan literasi berbasis komunitas digagas dengan antusias terutama oleh kalangan muda. Tidak saja dalam bentuk kampanye budaya membaca dan menulis, tetapi juga dalam kegiatan seperti pementasan seni, festival, atau pemberian penghargaan. Sebagai sesuatu yang dirayakan, maka sepatutnya dilakukan tinjauan atas tradisi literasi dari masa ke masa, dan historiografi Sulawesi Selatan.

Tradisi literasi Sulawesi Selatan tidaklah berlangsung secara berkesinambungan. Masa paling sukses terjadi pada kurun niaga, yakni sekitar abad ke16 dan abad ke17. Warisannya tidak saja tentang catatan kejayaan Kerajaan Makassar, tetapi juga berbagai bukti lain, baik tertulis, monumen fisik, hingga kemunculan tokoh-tokoh abadi sepanjang masa. "Keterbukaan" dalam pergaulan global, merupakan kunci kemajuan. Hal tersebut mendorong lahirnya masyarakat kosmopolis, yang menghargai keberagaman, juga turut memperkaya karya-karya literasi dari periode ini. Namun kejayaan tradisi literasi itu, seolah tenggelam saat Pemerintah Kolonial Belanda berkuasa sejak awal abad ke-18 hingga akhir periode kolonial. Dalam masa ini, tidak signifikan lahir karya-karya literasi.

Gairah literasi kembali muncul pasca kemerdekaan hingga tahun 1950-an. Adanya "kebebasan" dan hak yang sama sebagai warga negara yang "merdeka", mendorong berbagai kalangan mengekspresikan dirinya. Masyarakat plural lahir akibat perbauran antar berbagai latar belakang identitas yang berbeda. Kondisi tersebut memberi ruang atas munculnya karya-karya kreatif. Pada periode ini lahir puluhan kelompok seni, budaya, dan berbagai perkumpulan sosial kemasyarakatan. Karya literasi kembali muncul, di antaranya karya sasta, dan naskah rumusan pertemuan budaya, dan muncul pelaku-pelaku budaya yang mumpuni. Namun sejak Orde Baru, kehidupan budaya terutama di Kota Makassar mengalami senjakala dan miskin kegiatan kreatif masyarakat, termasuk tidak hadirnya karya literasi sesuai tuntutan zaman. 
Pasca reformasi, Makassar kembali mencoba meneguhkan diri sebagai entitas yang memiliki romantisme sejarah atas keagungan tradisi literasi. Salah satu kegiatan yang mengemuka terkait hal tersebut adalah diselenggarakannya Makassar international Writers Festival (MIWF) sejak tahun 2011. Sebuah kegiatan yang ditujukan sebagai usaha menjaga nafas literasi di Kawasan Indonesia Timur. Ada puluhan hingga ratusan penulis yang berbicara pada kegiatan ini setiap tahunnya. Selain memperkenalkan hasil literasi, berlangsung pula diskusi, workshop, pameran, pemutaran film, dan acara kreatif lain. Mendiskusikan karya dari tingkat lokal, nasional, hingga dari negara lain. forum ini ditujukan untuk para penulis, aktivis penerbitan, khalayak pembaca, dan pekerja seni dari berbagai disiplin. Kegiatan MIWF menjadi semacam perkenalan kembali; jejak, semangat, karya, dan capaian para tokoh literasi Sulawesi Selatan dan juga dari daerah lain di Indonesia, bahkan dunia internasional.

Berbagai bentuk usaha pengembangan dan perayaan literasi akhirakhir ini seperti acara MIWF dan acara bertema literasi lainnya, di satu sisi memberi harapan tersendiri. Namun di sisi lain - terutama jika dikaitakan dengan historiografi Sulawesi Selatan - akan menyadarkan bahwa ada berbagai kekosongan dalam penulisan sejarah Sulawesi Selatan, baik secara tematis, periodisasi, maupun metodologis. Sebagai objek penelitian, Sulawesi Selatan terutama pada periode klasik dan periode kerajaan, baik budaya maupun sejarahnya, telah ditulis dengan detail oleh banyak peneliti dalam negeri maupun luar negeri. Salah satu periode favorit tersebut adalah masa kejayaan kerajaan lokal, seperti Kerajaan Makassar (Gowa-Tallo), Kerajaan Bone, Kerajaan Luwu. Periode ini berlangsung pada masa pra-Islam, hingga saat kejatuhan Makassar di akhir abad ke-17. Penelitiannya hampir meliputi segala aspek kehidupan masyarakat, dari sejarah asal usul, budaya penduduk, kebesaran raja-raja, karya seni dan budaya, hingga adat istiadat. Ada banyak perdebatan yang mejadi argumen penggerak sejarah periode ini, seperti era niaga, kekuatan literasi, soial-politik, kekuatan armada perang, tradisi maritim, hingga letak geografis yang strategis. Penulis dalam negeri seperti Mattulada, Abd. Razak Daeng Patunru, Andi Zainal Abidin Farid, Abu Hamid, menampilkan nilai budaya lokal sebagai kekuatan sejarah Sulawesi Selatan. Sumber utama yang digunakan terutama adalah sumber lokal yakni lontaraq. Peneliti asing menggunakan cara pandang yang berbeda-beda, disertai penggunaan sumber asing. Ada yang fokus pada urgensi perdagangan global, kecemerlangan pemimpin lokal, relasi politik, hingga nilai-nilai budaya masyarakat. Beberapa di antaranya adalah Anthony Reid, Leonard Y. Andaya, William Cummings, Christian Pelras, Thomas Gibson, Gilbert Hamonic, Campbell C.Macknight, Roger Tol, dan lain-lain.

Pasca jatuhnya Kerajaan Makassar, dan mulai berkuasanya Pemerintah Kolonial Belanda, seolah menjadi akhir sejarah Sulawesi Selatan. Abad ke- 
18 hingga abad ke-19, tidak banyak kajian yang dilakukan baik oleh peneliti lokal maupun asing. Sedikit di antaranya yang menaruh perhatian adalah Heither Sutherland (Sutherland, dalam Nas (ed.), 1986); Sutherland, 2011: 53; Sutherland, dalam Tol, van Dijk, Acciaioli, 2009); Sutherland (with G.Knaap), 2005); Sutherland, in Henley (ed.), 2009). Penelitiannya terutama melihat peran Makassar yang tetap ada dalam perdagangan antar wilayah, seperti dalam komoditi hasil laut, atau perdagangan budak. Ada pula penulis produktif, Jacob Noorduyn yang menghasilkan berbagai karya tentang historiografi Bugis, terutama etos orang Wajo dalam perdagangan setelah kejatuhan Makassar. Abad ke-19 ditulis oleh Edward L. Poelinggomang dalam hal pasang surut pelabuhan Makassar sebagai pelabuhan bebas (Poelinggomang, 2002). Adapun kajian historis pada kekuasaan lokal maupun kehidupan penduduknya hampir tidak dilakukan.

Periode abad ke-20, juga belum mendapat perhatian yang memadai dalam historiografi Sulawesi Selatan. Sejarah politik awal abad ke-20 hingga akhir kolonial ditulis oleh Edward L.Poelinggomang. Periode pascakemerdekaan hingga tahun 1950-an, tema utama tulisan yang sudah dilakukan terkait dengan gejolak lokal dalam dinamika hubungan pusat-daerah, seperti yang ditulis Barbara Sillars Harvey dan Anhar Gonggong. Kajian singkat aspek kebudayaan tahun 1950-an dilakukan oleh Barbara Hatley. Periode setelah itu yakni Orde Baru hingga masa reformasi, belum pula mendapat perhatian serius.

Salah satu tema yang memiliki kekayaan data dan perlu dilihat dari berbagai perspektif adalah sejarah perkotaan pada abad ke-20. Sebagai contoh, Kota Makassar yang memiliki peran penting dalam dinamika politik dan relasi kekuasaan, maupun letaknya sebagi hub utama dan kota terbesar di kawasan timur Indonesia, belum dikaji lebih jauh. Padahal kota ini selalu memegang peran utama dalam konteks geo-politik. Kota ini juga berada dalam dekapan modernitas sepanjang abad ke-20. Meski demikian, hampir tidak ada tulisan sejarah yang secara khusus meneliti aspek kemodernan seperti produksi ruang modern, dinamika masyarakat modern, atau persoalan kota modern.

Kekosongan historiograsi pada beberapa periode dalam sejarah Sulawesi Selatan itu, coba diisi oleh pekerja kreatif dan literasi. Salah satunya adalah apa yang dikerjakan pihak penerbit lokal sejak era reformasi. Di antara penerbit lokal yang terdepan adalah Pustaka Refleksi yang berdiri tahun 2001. Dengan tagline "melawan" sentralisasi konten buku pelajaran yang didominasi penerbit dari Jawa, maka diterbitkan berbagai kisah, sejarah daerah, tokoh, mitologi, nilai budaya Sulawesi Selatan. Buku-buku yang diterbitkannya dikemas dalam bentuk ilmiah-populer dan menggunakan bahasa yang ringan, dengan alasan untuk menarik minat pembaca kalangan muda. Dalam waktu 10 tahun, telah menerbitkan 369 judul buku, dengan segala macam tema dan segala zaman. Kelompok penerbit ini pada tahun 2011, mendirikan Arus 
Timur, yang ditujukan guna memperluas jangkauan untuk menerbitkan aspek sejarah dan budaya terkait daerah Indonesia bagian timur.

Terlepas dari kesuksesan usaha penerbitan tersebut, terdapat kerisauan tersendiri dalam kaitannya dengan produksi karya sejarah dan budaya yang dapat dipertanggungjawabkan secara ilmiah. Sebagian besar karya yang diterbitkan bukan karya akademik, tetapi ditulis oleh siapa saja yang tertarik atas sejarah maupun budaya Sulawesi Selatan, seperti wartawan, tokoh masyarakat, penulis lepas, pensiunan, dan lain-lain. Meski tidak ditulis oleh sejarawan akademik, namun terbitan inilah yang menguasai pasaran bukubuku sejarah di Sulawesi Selatan, dan dipergunakan dari jenjang sekolah dasar hingga perguruan tinggi. Adapun penerbit yang fokus menerbitkan karya sejarah yang serius, seperti penerbit Ininnawa, secara kuantitatif tidak mampu mengimbangi dalam produksi maupun pemasaran.

\section{Kesimpulan: Kesadaran (Historis) Literasi}

Gaung gerakan literasi yang berkembang akhir-akhir ini, telah melahirkan semangat baru setidaknya pada peningkatan minat baca-tulis masyarakat. Tetapi perlu usaha lebih besar lagi guna membangun budaya literasi yang bertujuan untuk memecahkan persoalan kekinian masyarakat. Di samping itu, terdapat tantangan dalam mewujudkan transformasi nilai-nilai kultural tradisi literasi masa lalu di Sulawesi Selatan menjadi nilai yang melingkupi kehidupan keseharian masyarakatnya. Tidak terjadinya transformasi menyebabkan pula mengapa pada fase tertentu dihasilkan karya literasi yang penting, namun pada fase yang lain justru tidak ada karya literasi yang signifikan. Kondisi ini juga terjadi pada historiografi Sulawesi Selatan, dimana masih banyak periode tertentu yang tidak mendapat perhatian untuk penulisan dan penelitian sejarah yang memadai.

Dalam perjalanan sejarahnya, kemajuan literasi di Sulawesi Selatan ditentukan oleh adanya ruang kebebasan, keterbukaan, pergaulan lintas wilayah, serta penghargaan keberagaman. Pada masa kejayaan Kerajaan Makassar, karya literasi berkembang luas karena tercipta kehidupan kosmopolis yang mewadahi tumbuhnya ide-ide kemajuan. Hal itu juga terasa pada periode pasca-kemerdekaan dan tahun 1950-an, saat nuansa "kemerdekaan" dirasakan oleh segenap penduduk. Sebaliknya pada periodeperiode "pengekangan" atau "penyeragaman" seperti yang terjadi pada masa kolonial dan Orde Baru, akan membatasi lahirnya karya-karya literasi secara leluasa.

Salah satu tantangan soal literasi di Sulawesi Selatan saat ini yakni rendahnya perhatian dalam menjaga kelangsungan budaya literasi masa lalu. Pada umumnya karya agung masa lalu tidak menjadi nilai hidup, tetapi posisinya diletakkan semata-mata sebagai kebanggan dan sarana romantisme saja. Pada sisi lain, karya literasi "diperhatikan” terutama dalam kerangka 
tujuan politis. Sejak era reformasi, sejarah dan budaya lokal menjadi salah satu penopang ide otonomi daerah, pemekaran wilayah, dan gagasan "menciptaulang” kebesaran masa lalu. Secara umum, era reformasi yang diharapkan membawa usaha refleksi baru dalam kajian-kajian sejarah dan budaya belum menunjukkan hasil yang berarti. Belum muncul gairah yang kuat atas ruangruang perdebatan ilmiah guna mendorong berlangsungnya transformasi.

Pada pihak lain, penunjang berkembangnya tradisi literasi juga tidak begitu menggembirakan. Perpusatakaan sangat terbatas, dan yang tersedia tidak memiliki sentuhan cita rasa terkini, sehingga tidak menarik perhatian generasi muda. Toko buku dan lembaga penerbitan pun terbilang sedikit, sehingga semakin terbatas penggerak budaya literasi untuk tujuan membangun tradisi intelektual di segala kalangan.

\section{Daftar Pustaka}

A.B. Lapian (2009). Orang Laut, Bajak Laut, Raja Laut. Sejarah Kawasan Laut Sulawesi Abad XIX. Jakarta: Komunitas Bambu.

Abd. Razak Daeng Patunru (1993). Sedjarah Gowa. Ujung Pandang: YKSS.

Andaya, Leonard Y (2004). Warisan Arung Palakka. Sejarah Sulawesi Selatan Abad Ke-17. Makassar: Ininnawa.

Boxwer, C.R. (1983). Jan Kompeni. Sejarah VOC dalam Perang dan Damai 1602-1799. Jakarta: Sinar Harapan.

Brandes, J.L.A. (1920). Pararaton. Ken Arok. 's Gravenhage: Martinus Nijhoff.

Caldwell, Ian (1995). "Power, State and Society Among The Pre-Islamic Bugis". BKI 151.

Cummings, William (2015). Penciptaan Sejarah Makassar di Awal Era Modern. Yogyakarta: Ombak.

Edward L. Poelinggomang (2002). Makassar Abad XIX. Studi Tentang Kebijakan Perdagangan Maritim. Jakarta: KPG.

Edward L. Poelinggomang (2004). Perubahan Politik dan Hubungan Kekuasaan. Makassar 1906-1942. Yogyakarta: Ombak.

F Majid dan J.Mappanganro (2009). Makassar. Bagaimana Menjadi Kota Dunia? Yogyakarta: Ombak, 2009.

Geertz, Clifford (1980). Negara: The Theatre State in Nineteenth-Century Bali. Princeton: Princeton University Press.

Gibson, Thomas (2009). Kekuasaan Raja, Syeikh, dan Ambtenaar. Pengetahuan Simbolik dan Kekuasaan Tradisional Makassar 1300-2000. Makassar: Ininnawa.

Harvey, Barbara Sillars (1989). Pemberontakan Kahar Muzakkar. Dari Tradisi ke DI/ TII. Jakarta; Pustaka Utama Grafiti.

Kern, H. (1919). Het-Out-Javaansche Lofdicht Nagarakrtagama van Prapanca (1366 A.D). 's-Gravenhage: Martinus Nijhoff.

Kern, Richard (2000). Literacy and Language Teaching. Oxford: Oxford University Press.

Koerts, H.J. (2001). “Amtenar BB di Sulawesi Selatan”, dalam S.L. van der Wal (peny.), Kenang-kenangan Pangrehpraja Belanda 1920-1942. Jakarta: Djambatan.

Macknigt, Campbell (1993). The Early History of South Sulawesi: Some Recent Advances. Clayton, Victoria: Monash University Centre of Southeast Asian Studies. 
Mattulada (1985). Latoa. Yoyakarta: Gadjah Mada University Press.

Mattulada (1998). Sejarah, Masyarakat dan Kebudayaan Sulawesi Selatan. Ujung Pandang: Hasanuddin University Press.

Mattulada (2011). Menyusuri Jejak Kehadiran Makassar dalam Sejarah. Yogyakarta: Ombak.

Miller, George (2012). Indonesia Timur Tempo Doeloe, 1544-1992. Jakarta: Komunitas Bambu.

Muklis PaEni (ed.) (1986). Dinamika Bugis Makassar. Makassar: PLPIIS.

Mustari Bosra (2008). Tuang Guru, Anrong Guru dan Daeng Guru: Gerakan Islam di Sulawesi Selatan 19141942. Makassar; La Galigo Press.

Pires, Tome (2016). Suma Oriental. Perjalanan dari Laut Merah Ke Cina dan Buku Francisco Rodrigues. Yogyakarta: Ombak.

Rahman Rahim (2011). Nilai-nilai Kebudayaan Bugis. Yogyakarta: Ombak.

Reid, Anthony (1980). "The Structure of Cities in Southeast Asia, Fifteenth to Seventeenth Century". Journal of Southeast Asian Studies. Vol.11 (2).

Reid, Anthony (2004). Sejarah Modern Awal Asia Tenggara. Sebuah Pemetaan. Jakarta: LP3ES.

Reid, Anthony (2009). "Pluralisme dan Kemajuan Makassar Abad ke-17”, dalam Roger Tol, Kees van Dijk, Greg Acciaioli, Kuasa dan Usaha di Masyarakat Sulawesi Selatan. Makassar: Ininnawa.

Republik Indonesia (1953). Propinsi Sulawesi. Kementerian Penerangan.

Ricklefs, M.C. dkk. (2013). Sejarah Asia Tenggara. Dari Masa Prasejarah sampai Kontemporer. Jakarta: Komunitas Bambu.

Rossler, Martin (2009). "Dari Keturunan Dewata ke Pemerintahan Pusaka Keramat dan Perubahan Politik di Dataran Tinggi Goa”, dalam Roger Tol, Kees van Dijk, Greg Acciaioli, Kuasa dan Usaha di Masyarakat Sulawesi Selatan. Makassar: Ininnawa.

Sartono Kartodirdjo (1992). Pengantar Sejarah Indonesia Baru: 1500-1900. Dari Emporium sampai Imperium. Jakarta: Gramedia.

Skinner, C. (ed.) (2008). Syair Perang Mengkasar/ Makassar. (Makassar: Ininnawa.

Slametmulyana (1979). Negarakretagama dan Tafsir Sejarahnya.Jakarta: Bhratara Karya Aksara.

Sutherland, Heather (1983). "Slavery and the Slave Trade in South Sulawesi, 1660s-1800s" dalam Anthony Reid (ed.) Slavery, Bondage and Dependency in Southeast Asia. St.Lucia: University of Queensland Press.

Sutherland, Heather (1986). "Ethnicity, Wealth, and Power in Colonial Makassar: A Historiographical Reconsideration”, dalam Peter J.M. Nas (ed.), The Indonesian City. Studies in Urban Development and Planning. Holland: Foris Publications.

Sutherland, Heather (2005). "Monsoon traders: Ships, skippers and commodities in eighteenth century Makassar (with G.Knaap). Leiden: KITLV Press.

Sutherland, Heather (2009). "Money in Makassar" in P.D.B.Henley (ed.), Credit and Debt in Indonesia, 1860-1930: From peonage to pawnshop, from kongsi to cooperative. Singapore \& Leiden: ISEAS \& KITLV, 2009.

Sutherland, Heather (2011). "Whose Makassar? Claiming Space in a Segmented City", Comparative Studies in Society and History: 53 (4).

Sutherland, Heather. (2009). "Teripang dan Perahu Wangkang. Perdagangan Makassar dengan Cina pada Abad ke-18”, dalam Roger Tol, Kees van Dijk, Greg Acciaioli, Kuasa dan Usaha di Masyarakat Sulawesi Selatan. Makassar: Ininnawa. 
Vlekke, Bernard H.M. (1943). Nusantara; A History of the East Indian Archipelago. Massachussets: Harvard University Press.

Warren, James Francis (1981). The Sulu Zone 1768-1898. The Dynamics of External Trade, Slavery, and Ethnicity in the Transformation of a Southeast Asian Maritime State. Singapore: Singapore University Press.

Wolhoff dan Abdurrahim (1959). Sedjarah Goa. Makassar JKSST. 